\title{
Realising a socially sustainable South African society through cooperative learning
}

\author{
KLG TEISE ${ }^{1}$
}

\begin{abstract}
Education conceptualised in terms of the broader project of socially sustainable development (SSD) makes cooperative learning (CL) valuable in realising the former. Cooperative learning emphasises cooperation as integral to learner success, and because of this CL strategies have been found to be successful in fostering positive intergroup attitudes in classrooms, multicultural and otherwise. Social sustainable development concerns those aspects of human life and human relations which are necessary for the survival of society. Apart from it being particularly instrumental in improving learners' academic performance, CL is equally valuable in promoting positive social relations amongst group members. Such relations are important for achieving social sustainable development. Therefore, CL could particularly be valuable to develop in learners, and the broader society, the social dispositions required for a socially sustainable South African society. My argument centres on the potential of CL as a practical strategy towards the development of a social sustainable South African society. In an attempt to demonstrate that CL holds the potential to contribute towards a social sustainable South African society, I'll be focusing on the core tenets of SSD. These tenets are explored in relation to the principles and social outcomes of CL in order to establish the extent the latter could be instrumental in promoting SSD.
\end{abstract}

Key words: Socially Sustainable Development; co-operative learning; South African education; learning

\section{Introduction}

In order to realise socially sustainable development (SSD) South Africa (SA) adopted sustainable development (SD) as a policy goal. However, realising the vision of a socially sustainable society not only requires concerted efforts of all South Africans, but also a strong willingness and an ability to cooperate with each other, especially since "... South Africa belongs to all who live in it" (RSA 1996). South Africans are therefore individually and collectively responsible to bring about a socially sustainable society. One way of realising that is through cooperation. Johnson et al. (1994) defines cooperation as the ability to work together to achieve a common goal. Common goals define appropriate behaviour and

1. School of Education Studies, University of the Free State, P.O. Box 339, Bloemfontein 9300, South Africa. Email: teisekl.hum@ufs.ac.za 
improve the quality of life within a community (Johnson et al. 2007). In South Africa, the common goal and also the vision of a socially sustainable South African society is articulated in the South African Constitution, Act no. 108 of 1996. Realising a socially sustainable society through cooperation is therefore constitutionally mandated, especially in light of the apartheid past.

Education, but particularly South African education is regarded central in realising SSD. However, an approach to education and learning is required which would effectively promote and develop the values of SSD. In this paper I argue that cooperative learning (CL) holds the potential to develop and promote values for SSD. In my argument, I'll first be conceptualising learning for SSD. Thereafter, I'll be exploring the concepts cooperative learning and social sustainable development. In the last part of this paper I will draw links between cooperative learning and social sustainability to demonstrate the potential CL holds for developing the skills and values of SSD.

\section{Re-conceptualising learning for social sustainable development}

Education is key to SD and SSD (Chapter 36 of Agenda 21 (UNCED, 1992). However, traditional education and its related learning approaches are blamed for creating and upholding unsustainable development and rendering society unsustainable (Calder \& Clugstone 2005; Gadotti 2008; Sterling 1996). Jackson (2011:28) also claims that social transformation involves types of learning that are not at presently recognised or practised in education. In this regard the South African department of education also expressed a concern that "many teachers rely on teaching methods that do not engage learners in active learning" (DoE 2003). Hence it calls for an overhaul of the ways in which the official curriculum is delivered.

Sustainable development therefore not only requires a re-conceptualisation of learning. Rather it requires deep, transformative learning which would not only lead to new ways of thinking, alternative values, co-operation and more reflexive citizens but also to the construction of a transformed and entirely new world view (Jackson 2011; Wals 2011). Martin et al. (2006) assert that such learning should lead to individual behavioural changes, as well as social change. One could therefore assume that within the SA context, learning for SD should imbue learners with alternative values than the ones associated with apartheid education. Such learning should therefore not only give effect to the vision of the Constitution and the vision of SSD, but also to learners developing a new outlook on their individual and collective responsibility towards realising both visions. Since the habits of the mind and the habits of the heart, the habits that inform the democratic ethos are not inherited (De Tocqueville 1969) they need to be developed through education. South African education therefore needs to embrace learning which would cultivate values and behaviour that is supportive of SSD.

South African education, prior to 1994, was informed by the traditional paradigm (Botha 2002), which rendered society socially unsustainable by creating and reproducing racial, gender, class and ethnic divisions and inequalities in both education, and in society (Weldon n.d.; Muthivhi \& Broom 2008). The adoption of a new Constitution in 1994 saw the values of the traditional educational approach in contrast with its vision, and therefore unfit to promote SSD and to sustain the democratic project of SSD. Education was subsequently 
transformed and Curriculum 2005 (C2005) - an outcomes-based approach to educationadopted. However, implementation challenges saw C2005 revised numerous times since its implementation, and more recently into the Curriculum and Assessment Policy Statement (CAPS) (2011).

The CAPS stipulates policy on assessment in SA schools, but it also contains the amended National Curriculum Statement Grades R-12, which gives expression to the knowledge, skills and values worth learning in South Africa (DBE 2011). As such, the NCS (2011) not only aims to equip learners with knowledge, skills and values for meaningful participation in society as democratic citizens, but it also embraces social transformation, active learning, human rights, inclusivity and social justice (DBE 2011). In principle, the NCS aspires to create learners that will be imbued with the values of democratic citizenship, social justice, human rights and equality - values that were lacking in previous educational aims and objectives. Given its nature and aims, I contend that cooperative learning, despite it being "underestimated and underutilised in schools" (Al-Yaseen 2011) provides a reconceptualisation of learning which would promote the internalisation of these values and so realise a socially sustainable South African society.

\section{What is cooperative learning $(\mathrm{CL})$ ?}

Various definitions of what CL entails are found in the literature. However, all view CL as a strategy where learners learn to work cooperatively in groups to attain collective outcomes. Killen (2010; Smith 2000) defines CL as an instructional technique in which learners work together in small groups to help each other achieve a common learning goal. Slavin (1990) adds the element of equality as an imperative when defining $\mathrm{CL}$ as a social method which involves students working together as equals to accomplish something of importance to all.

Cooperative learning subsequently rejects selfishness, individual competition and unequal power relations. Rather, it deliberately emphasises the group, its cohesion, common progress and the equality of team members. Hence Killen (2010 Schul, 2011; Smith 2000) warns that CL should not be mistaken for group work or for having a group of students sitting side-byside at the same table talking to each other while doing their individual assignments. For such group work will not necessarily yield the social outcomes of CL, as they might not attain its common goal, whilst prejudice, biasness or unequal power relations might still be prevalent amongst group members (Georgiadis et al. 2011). Guided by principles of positive interdependence, individual accountability, interpersonal skills, face-to-face interaction, group processing and equal participation CL places particular demands on the teaching and learning process (Johnson \& Johnson 2010; Parveen et al. 2011; Smith 2000). It is therefore only when these demands are met, that CL is taking place and space is created to effectively realise the common aims and objectives of the group, and develop the social dispositions required for $\mathrm{SS}$.

In addition, $C L$ is also a form of active learning (Tsay \& Brady 2010). Active learning is conceptually defined as "anything that involves students in doing things and thinking about the things they are doing" (Onwuegbuzie et al. 2009). As such, CL requires that learners not only 'do' things, but also reflect on and analyse what they are doing. Reflection is the key to what it means to be involved in ESD (Wade \& Parker 2008). It therefore enables people to critically evaluate their ideas and actions pertaining to SSD, and change it accordingly. 
Cooperative learning could therefore be a valuable educational and social tool in transforming the post-apartheid South African society and education, especially since it is intrinsic to social reconstructivism (Killen 2010; Schrueder 1998; Steyn \& Wilkinson 1998). As one of the theoretical frameworks of South African education, social reconstructivism supposes social transformation. In addition, social reconstructivism also assumes learners who do not passively receive information, but are actively involved in the learning process by constructing their own knowledge.

Given the possible value CL holds for social transformation, South African education's commitment to democratic and responsible citizenship as educational outcomes is therefore significant to CL. Hence the statement "we are all responsible for the advancement of our nation ... and ... we are all responsible, too, to others in our society, for our own behaviour" (DoE 2001). In addition, not only is South African education principally based on the value of accountability (DoE 1995), but the National Curriculum Statement (2011) is grounded on the principle of active learning (DBE 2011). The NCS also aims to develop learners who cannot only work cooperatively as individuals and with others as members of a team, but who are also able to critically evaluate information and communicate effectively (DBE, 2011). Since these outcomes are all linked to CL, South African education has an obligation to advance CL in order to realise SSD.

\section{What is socially sustainable development (SSD)?}

Social sustainable development is integral to SD. Hence Chan Lean Heng's (2006) warns that no society can sustain ably, nor can its members live in dignity and peace if there is inequality, injustice, prejudice or discrimination of any group. Societies characterised by social inequality and inequity will therefore not be sustainable.

Although efforts to define SSD are still in its formative phase (Magis \& Shinn 2009), SSD conceptualised in terms of social justice, concerns the human dimension of SD. As such it addresses inter alia issues such as equity, human rights, racism, poverty, accountability and peace (Fernando 2003; Foley 2004; Landorf et al. 2008). Social sustainable communities are also equitable, diverse, connected, and democratic and provide a good quality of life (McKenzie, 2004). In addition, for Colantonio (2007) the maintenance and development of social capital is relevant to SSD, especially in the context of the need to foster trusting, harmonious and co-operative behaviour to underpin civil society.

South Africa envisions a socially sustainable society. This vision is articulated in the Constitution which aims to

$$
\begin{aligned}
& \text { [h]eal the divisions of the past and establish a society based on democratic values, social } \\
& \text { justice and fundamental human rights; } \\
& \text { [i]mprove the quality of life of all citizens ...; } \\
& \text { [l]ay the foundations for a democratic and open society ...; and } \\
& \text { [b]uild a united and democratic South Africa (RSA 1996). }
\end{aligned}
$$

In principle, this vision entails the promotion and advancement of democracy, equity, social justice and equality, non-sexism and non-racism, tolerance, respect, Rule of law, accountability, transparency, human dignity (RSA 1996). The advancement of this vision 
and principles are relevant because for the South African people, they embody the dream of a SSD, and a break with social unsustainability characterised by inequity, inequality, racism, sexism and social injustices.

South African education has a particular role to play in realising SSD. However, it cannot be business-as-usual for education. Hence the call for "appropriate education and training [which would] empower people to participate effectively in all processes of democratic society ... community life, and can help citizens building a nation free of race, gender and every other form of discrimination" (DoE 1995). It could be assumed that appropriate education not only entails the creation of appropriate teaching opportunities. Learning opportunities should also be designed in a fashion that would empower learners to contribute towards social sustainability.

In addition, the education system taken as a whole "embodies and promotes the collective moral perspective of its citizens that is the code of values by which the society wishes to live and consents to be judged: (DoE 1995). We are furthermore promised that all new education and training policies to address the legacies of under-development and inequitable development will be based principally on the constitutional guarantees of equal educational rights for all and their implementation and formulation must observe all other constitutional guarantees and protections (DoE 1995). The DoE (2003) also commits itself to develop learners imbued with the values of the Constitution and who act in the interest of a society based on respect for democracy, equality, human dignity, life and social justice. These bold statements and promises not only place South African education in the centre of realising a social sustainable society, but in principle create space to realise this through CL.

\section{What is the relationship between cooperative learning and socially sustainable development?}

The value of CL in realising academic outcomes is well-known. Various authors also allude to the particular value of CL in developing in learners sound social outcomes (Johnson et al. 2007). These outcomes resonate with the tenets of SSD which are: human well-being; democracy, equality and equity; capital and human rights (Magis \& Shinn 2009; McKenzie 2004; Pronk 1981). In the discussion that follows, these tenets are explored in relation to the principles and social outcomes of CL in order to establish the extent to which the latter could be instrumental in promoting SSD.

\section{a) Human well-being}

Sustainable development, and thus SSD focus on the well-being of people as the ultimate goal of all development policies (WCED 1987). Human well-being concerns basic goods or services as well as fundamental human rights, democratic participation, social justice and equality, needed to meet a minimum standard of living (Dresner 2008; Elliot 1999; Koning 2001). This amounts to different freedoms, political rights and accountability; transparency; skills, dialogue and organisation and social interaction and the creation of an environment where people can develop their capabilities and enjoy long, healthy, and creative lives (Blewitt 2008; Harkness 2007; Magis \& Shinn 2009; McCarthy 2009; Rist 2008; Sen 1999). As such, human well-being, relate directly to people's ability to sustain themselves and to influence the world around them. The concept 'well-being' is therefore primarily conceptualised in terms 
of the fulfilment of basic needs, human development and freedom. SSD is subsequently realised when the basic needs, human development and needs for freedoms of people are met.

Cooperative learning could advance human well-being by promoting the progress of each team member. Promoting each others' progress places a particular responsibility on group members. In CL it entails assisting, helping and supporting one another, exchanging needed resources and information, giving moral support, encouraging one another positively, influencing one another's efforts, acting trustworthy and being motivated to strive for mutual benefit and to achieve the goal together (Boondee et al. 2011; Johnson \& Johnson 1991). As such, CL not only requires provision in members' basic needs, but also for members to learn to know each other. Johnson and Johnson (1991) assert that knowledge of each other as persons forms the basis for caring and committed relations. Concern for the well-being of others is therefore advanced by developing in learners skills and dispositions characterised by a selflessness, respect for others, caring for one another, considering each others' well-being and being sensitive to and providing in the needs of others. Furthermore, promoting the progress of each member, assumes a relationship where members depend on one another, and as such is responsible for one another.

\section{b) Democracy}

Democracy is central to achieving a SSD, as the latter requires a political system that embraces effective citizen participation. Democracy not only implies democratic government, but also democratic governance. Since both are perceived to promote human development, SSD cannot be pursued in the absence thereof (Bäckstrand 2006; Huh 2011; Munasinghe 2009). The application of democratic principles is subsequently regarded as necessary conditions for SSD. Democratic government and democratic governance assumes particular principles, values and dispositions which relate to democratic representation, transparency and social participation, but also to accountability, equity and equality, inclusion, fundamental freedoms; non-discrimination and respect for human rights (Bäckstrand 2006; Blewitt 2008, Fernández 2004). As such, the implementation of these principles, values and dispositions therefore holds the potential to ensure the realisation of a SSS.

Cooperative learning is grounded in individual responsibility. Boondee et al. (2011) regards individual responsibility an important requirement for the strength and success of the group. Individual accountability, assumes that each member is responsible for a particular part of the work or learning (Killen 2010). However, as members share the responsibility of the progress of the team, responsibility is divided and members are held responsible for not only their own progress and success but also that of the group (Boondee et al. 2011; Johnson \& Johnson 1991). Not only is responsibility valuable for promoting and advancing the aims and objectives of the group, but Johnson and Johnson (1991) asserts that mutual responsibility is the great central principle of democracy. The emphasis CL places on accountability also signals its potential to develop in learners sensitivity for human rights, especially since there can be no democratic rights without responsibilities.

Cooperative learning could furthermore promote democracy through sound interpersonal and small group skills which ensures that group members interact with each other, listen attentively, question and clarify ideas, negotiate, and peacefully resolve differences (Killen 2010). Al-Yaseen (2011) also maintains that CL stresses the importance of communicative capacity as a means to build trusting relationships. Possession of interpersonal and social 
skills subsequently creates opportunities for group members to develop communicative virtues which will enable them to state their views without interruption, to be listened to and not be forced to adopt a particular view. Communicative virtues are important for it is not only through knowing, trusting, accepting and supporting one another that the group will accomplish success (Roger \& Johnson 1994), but also through creating conditions where members engage critically and deliberate with each other in an environment that is free from prejudice and bias (Boondee et al. 2011). Space is therefore created for free and open dialogue where ideas and (mis)conceptions could be challenged. As such through interpersonal and small group skills, learners not only develop and are sensitised about democratic citizenship (Killen 2010; Slavin et al. 2001), but the values and principles of democratic citizenship and a socially sustainable society are also realised.

Furthermore, since interpersonal and small group skills also promote decision-making, constructive conflict management, trust in others and effective communication, (Johnson \& Johnson 2010; Tsay \& Brady 2010), CL positively contribute towards social capital and the cohesiveness of the group.

In addition, $\mathrm{CL}$ also nurtures democratic values such as concern for others whilst it promotes diverse relationships and social interaction regardless of differences, by developing in learners anti-discriminatory tendencies (Schul 2011; Sharan 2010; Govaris \& Kaldi 2008). Cooperative learning could also develop in learners' empathy towards other peoples and cultures and it promote respect for one another (Killen 2010; Slavin et al. 2001). As such, CL promotes inclusion.

\section{c) Equity}

Regarded as basic to every concept of justice, equity implies fairness in the distribution of basic social goods, such as liberty and opportunity, income and wealth and social respect (Baker 2006). Equity is broadly concerned with the elimination of institutionalised domination and oppression and with the distribution of benefits and burdens throughout the society (Enslin 2006; Foley 2004). As such, equity calls for more emphasis to be placed on the needs of the poor, vulnerable and the disadvantaged. As a constant theme in all discourse on SSD, equity assumes a commitment to fairness in the distribution of gains and losses, and the entitlement of everyone to an acceptable quality and standard of living (Deb 2009; Dillard et al. 2009; Dresner 2008; Landorf et al. 2008;).

However, equity cannot be achieved without equality. Conceptualised as sameness or equal treatment, equality is not only an important requirement for social justice, but since inequity results in for example unfair treatment and discrimination, it is also perceived to being an integral part of the problem(s) of SD and the driving force behind unsustainability (Langhelle 1999; McLaren 2003; Rao 2000). As equality, and therefore also equity, are crucial elements of social justice (Heyneman 2004; Pendlebury \& Enslin 2004; Schultz 2007) it could be argued that social justice is a defining characteristic of SSD. To achieve social justice, and therefore SSD, all people will therefore have to be treated equally and equitably. As social justice is an ideal of governments (Schultz 2007), ideals to achieve SSD aims and objectives should therefore specifically be underpinned by the peoples' social justice needs.

CL advance equity and equality by promoting equal participation of team members. Parveen et al. (2011) claim that in CL, equal participation ensures that no students dominate another student socially or academically. Slavin (in Slavin \& Cooper, 1999) also asserts that if 
learners work and get to know one another as equals they become friends and find it difficult to hold prejudices against one another. In the same breath Allport (in Slavin 1990) asserts that:

\section{Prejudice ... may be reduced by equal status contacts between majority and minority groups in the pursuit of common goals. The effect is greatly enhanced if this contact is sanctioned by institutional supports... and if it is of a sort that leads to the perceptions of common interests and common humanity between members of two groups.}

As such, in CL no room exists for unequal power relations. Team members should therefore embrace and respect diversity and treat each other equitably and fairly, irrespective of their social status, gender roles, sexual orientations, religious convictions, physical abilities or any other differences. As such, CL moves beyond discrimination by assigning equal status roles to students irrespective of their differences. Promoting equity and equality is therefore also indispensable to sustain the democratic project. By advancing equity and equality CL holds the potential to contribute towards realising SSD.

\section{d) Social capital}

Regarded as a "sine qua non of stable liberal democracy" and the "glue that holds societies together" (Feldman \& Assaf 1998; Fukuyama 1999), social capital is the attribute of communities. It is shaped through interactions and norms and values that are socially held. Social capital embraces particular features of society, such as trust, norms and networks, information, commonly held values; mutual understanding, conflict resolution, problem identification and solving, socially held knowledge, reciprocity, dialogue, exchange, sanctions, interdependence, co-operation and connectedness (Adams 2009; Asadi et al. 2008; Blewitt 2008; Koning 2001; Kilpatrick et al. 2001; Messer \& Kecskes 2009). It is assumed that these principles would contribute towards improving social cohesion and the efficiency of society by facilitating coordinated actions and enabling people to work in groups to achieve a common goal. Through social cohesion South Africans could mobilise and collectively act to overcome social challenges they are faced with on a daily basis, for mutual benefit. The aspirations for social capital, strong social ties and social cohesion are officially articulated in South Africa's motto "Unity in Diversity".

In CL social cohesion comes to play in the assumption that students will help one another to learn because they care about one another and want one another to succeed (Killen 2010; Slavin 1996). Cooperative learning provides a learning laboratory where students develop empathy and concern towards other people, a commitment to the values of fairness and social responsibility, and the ability and inclination to act on these values in everyday life (Schul 2011; Slavin et al. 2001). 'Care', 'concern' and 'empathy' are all related to the notion of compassion. Compassion focuses more on the other and less on the self. It therefore pushes the boundaries of the self outward by focusing on others (Waghid 2003). Nussbaum (in Waghid, 2003) explicitly link compassion to CL when stating "in order for compassion to be present, the person must consider ... another [person] as a significant part of his or her own scheme of goals and ends". As such, the value of compassion in CL assumes that members put their individual self-interest second and focus on the needs of every individual member in the group in order to promote the cohesiveness of the group and to realise the groups' aims and objectives. 
Johnson and Johnson (1995) claim that cohesive groups tend to show greater commitment to the social goals of the group, and feelings of personal responsibility to the group and the willingness to defend the group. Members will therefore look out for another, support one another, be sensitive to the needs of another and share resources with one another. Cooperative attitudes are also related to mutual acceptance, respect, liking and trust amongst students (Johnson \& Johnson 1991). Positive interdependence is therefore central in fostering social cohesion as an attribute of SSD.

Smith (2000) regards positive interdependence as the heart of CL. Positive interdependence, exists when individuals perceive that they can reach their goals if and only if the other individuals with whom they are cooperatively linked also reach their goals (Johnson \& Johnson, 1991). Therefore, positive interdependence assumes that the failure or success of the individual is intrinsically bound to the failure or success of the group. Since the whole team will suffer if one member does not do his or her work, the interdependence on one another is strengthened (Tsay \& Brady 2010). Therefore, positive interdependence not only fosters feelings of connectedness - a sense of belonging to a group, but it also develops group cohesiveness and unity. As such, positive interdependence promotes a strong sense of (inter)dependence and trust amongst members, and it assumes that members will share whatever is at their disposal in order to enable everybody and the group to succeed.

\section{e) Human rights}

A sustainable society protects and promotes the human rights of its citizens. Since human rights are integral to a sustainable society, education has a responsibility to protect and promote these rights. Human rights are unalienable entitlements based on morality, justice and fairness which all people ought to have, and it occupies a specific place within SSD. For Haughton (1999) SD has enlarged the consideration of rights through its explicit attention to the rights of present-day socially marginalised groups. For Landorf et al. (2008; Agyerman et al. 2003) SD should also encompass human rights issues of racism, democracy and peace, equality and participation. As basic human rights, these should be upheld and protected by all governments, and promoted through education. Since human rights envision well-being they directly impact on the human condition. Hence, when realised, human rights can ensure an environment supportive of SSD. It therefore follows that the absence of a human rights approach could impede upon the realisation of the aims and objectives of a socially sustainable society.

Cooperative learning embraces human resources issues in various ways. For example, CL supposes and embraces equity and equality but it also promotes values and dispositions of democracy, communication, deliberation and participation. In addition, CL also promotes diversity by embracing the inclusion and acceptance of learners with special educational needs (Brandt 1991; Slavin et al. 2001). Johnson and Johnson (2008) also regard CL to be instrumental in promoting peace, whilst Slavin and Cooper (1999) asserts that CL has the potential to facilitate the building of cross-ethnic friendships, and to reduce racial stereotyping, discrimination and prejudice. Furthermore, CL not only promotes concern for others but also respect for diversity (Killen 2010; Schul 2011; Slavin et al. 2001; Tsay \& Brady 2010). As such, not only does it advance the acceptance of each other, but it also validates and appreciates diversity, and promotes social cohesion. Similarly, the potential CL holds for peaceful conflict resolution should also be acknowledged. 
However the effective implementation of $\mathrm{CL}$ and the realisation of SSD will more likely take place in classroom and school conditions that are conducive to teaching and learning. Teachers should therefore consider the importance of a conducive learning environment, since none of the promises of CL will be realised unless an environment in which they are possible, is created (Wohl \& Klein-Wohl 1994; Killen 2010). A conducive learning environment is amongst others an environment characterised by learner-centeredness and active learner involvement (Maceiras, Cancela, Urréjola \& Sanchez 2011; Tsay \& Brady 2010); effective classroom design (Johnson, Johnson \& Holubec 1994); and manageable learner numbers (Schul 2011). It is assumed that these conditions would not only promote CL but also contribute towards SSD.

However, certain complexities and challenges within the South African education context hold the potential to hamper the effective implementation of CL and the subsequent realisation of SSD. For example, Harley and Wederkind (2004) claim that in South African classrooms, teaching does not approximate learner-centeredness. Harber and Mncube (2011) cite research suggesting that teachers continue to use traditional, teacher-centered methods of monologue and rote learning. Furthermore, referring particularly to the teaching of mathematics (but also applicable to education in general), Sekao (2004) claims that the application of CL methods is not only made difficult by the large group sizes emanating from large class sizes, but that these conditions also result in huge time loses as teachers try to manage off-task behaviour. As such, not only does maintaining discipline in large classes become a serious challenge to teachers, but it also negates the effective implementation of $\mathrm{Cl}$. In addition, according to Murdoch and Wilson (2008) CL runs more smoothly when the physical environment is supportive. However, large classes makes it difficult for teachers to create a supportive physical environment, by arranging furniture and designing the classroom space as to maximise social contact amongst students, maintaining eye-contact and have easy access to each other, the teacher and the materials they might need. Coupled with these, inadequately trained teachers (Van Deventer 2009; Shreuder 1998); a rather shallow understanding of the principles of OBE (and thus CL)(Harley \& Wedekind 2004); haphazard planning and time management (Bloch 2009), to mention a few, are some of the contributing complexities found in South African education which might jeopardise the successful implementation of CL as the subsequent realisation of SSD.

\section{Conclusion}

Schools are societal institutions, established amongst others to realise the aims and objectives of society. Whilst in the past education was used to strengthen social divisions, education now has to bring South African closer together. I agree with Giroux (1995) that through public schools, learners can be taught the values and skills necessary to administer, protect and perpetuate a free democratic society. It is therefore imperative that those learning approaches which could advance South Africa's democratic project be promoted and validated. Especially since apartheid education perpetuated a socially crippled society marked by gender and racial stereotypes, tensions and discrimination, which caused divisions and a rift between the people of South Africa. Uniting the people of South Africa behind a common goal - to build a democratic and free society where diversity is respected and equality and equity and non-discrimination reign - is therefore equally the responsibility of education. 
Provided that they embrace the goal and vision of a new South Africa, teachers would regard the racially integrated and inclusive nature of schools as an asset, rather than a burden, through which they could develop in learners the skills and dispositions for democracy.

South Africans might not be to, or know how to or probably want to work cooperatively to bridge the divisions of the past. This not only hampers cooperation between and the coexistence of various groups but also the sustainable of the South African society. Teaching and learning strategies which would cross these divisions, and bring learners and ultimately South Africans closer together are therefore relevant and should be validated. Since healing the divisions of the past and overcoming social stereotypes and racial tensions, is not going to happen spontaneously it is imperative that South African schools promote cooperative habits and dispositions in order to build a new and sustainable South African society, for without cooperation, South Africans will not realise a socially sustainable society.

Cooperative learning appears to be relevant in developing in learners the dispositions required for cooperation and democracy. I argued that CL is potentially fit to advance a socially sustainable society. Democracy assumes that everybody's ideas should be validated and acknowledged. Cooperative learning's fitness to promote social sustainability lies in its potential to equip learners with skills, values and the right attitudes to look beyond social differences, and respect and appraise the rich diversity of the country and reach out to 'other people' in the safe and conducive environment provided by the school and classroom. Part of these includes the ability to listen to others instead of having your views forced down on other people, or having your views ignored. Listening demonstrate a concern and a respect for others. In addition, not only does CL promote effective communication, but it also advances rational deliberation.

In addition, by promoting equality and fairness in the group CL contribute towards eradicating social barriers which might still divide the people of South Africa, and threaten sustainability. There is a strong need for marginalised and oppressed learners to be heard, validated and acknowledged, and for stereotypes to be broken. By effectively implementing CL classrooms could become safe havens; free from inequality, separation and discrimination, and places where diversity is embraced. The social status of a learner or his/her ability should therefore not impede upon his/her self-worth or being intimidated by the social status of another learner. No learner should therefore feel inferior or superior.

Social sustainability depends amongst others on active citizenship and reflection. Cooperative learning holds the potential to transform classrooms from places of passive social interaction, into places of active social interaction and reflection. In such an environment learners learn from one another and can confront and challenge their own prejudice. In addition, reflection upon the self, and challenging 'the own' could lead learners to a better understanding of themselves and who they really are. With such knowledge learners are able to defend the good in 'their own' or reject that which hampers free and spontaneous social interaction and cooperation.

South Africa's bad human rights track record demonstrates that concerted efforts are needed to promote and advance the rights many fought for and which are now the basis of our democracy. South Africa's commitment to human rights is therefore central to both democracy as well as government's obligation to realise a sustainable society. Whilst the promotion of human rights is integral to education, CL could not only sensitise learners about their rights but also that of others in the group. However, there cannot be any 
entitlement to rights without also accepting the corresponding responsibilities. By also emphasising the responsibility of each learner towards achieving common aims and objectives, learners could develop a sense of responsibility towards others in society.

The South African society is riddled with crime and corruption. As forms of social capital, these social challenges not only negatively impacts upon relationships of trust, but it also weakens social ties and impedes negatively on social cohesion. In the face of mistrust, corruption and dishonesty, social networks which are supposed to strengthen social cohesion are difficult to establish and social structures cannot function effectively. However, CL could develop and strengthen the values of trust and honesty through social engagement as it takes place within the groups. In this way learners are exposed to the moral demands of societal networks and institutions. In addition, social capital could also promote a sense of belonging and pride in the group. This could particularly be valuable for South Africans who need to unite in their diversity.

In the final analysis, no group or society can be sustained if the basic needs of all its members are not met. Part of the reasons why South Africa was socially unsustainable during apartheid, was because the basic needs of all people were not met. In addition, education was cleverly used to justify and promote inequality in meeting the basic needs of Black South Africans. It is therefore imperative that through education currently, opportunities are created for all people to meet their basic needs. By acknowledging that every learner has particular needs cooperative learning creates a space for education to meet the basic needs of the disadvantaged, the marginalised and the voiceless. Through CL these needs which broadly relate to the need to be respected, heard, appreciated and valued irrespective of the social background or ability of the learner, is promoted, and so contribute towards a sustainable society.

Working cooperatively enables learners to develop social skills which they should carry forward into adulthood and into the community. Geared with these skills, learners could act as agents of change by challenging unsustainable social practices of injustice, inequality, discrimination and exclusion. CL therefore holds the potential to develop a new culture of respect for one another, compassion, and tolerance. In addition it could advance the value of ubuntu/botho which is so integral to the aims and objectives of the South African Constitution, Act 108 of 1996, and central to a sustainable South African society. The South African society still bears the scars of social unsustainable development. Getting people to work cooperatively is important if we want to overcome these divisions and heal the scars of the past. CL could promote tolerance and acceptance of diverse social groups, and so foster and promote positive social relationships amongst diverse learners. In this paper I argued that, as a form of learning cooperative learning could be a valuable tool to truly unite people in an effort to realise a socially sustainable South African society.

\section{Bibliography}

Adams WM 2009. Green Development: Environment and Sustainability in a Developing World. $3^{\text {rd }}$ Edition. London: Routledge.

Agyeman J, Bullard D, Evans B 2003. Just Sustainabilities: Development in an Unequal World. London: Earthscan Publications Limited. 
Al-Yaseen WS 2011. Expectations of a Group of Primary School Teachers Trained on Cooperative Learning on the Possibility of Successful Implementations. Education, 132(2): 273-284.

Asadi A, Akbari M, Fami HF, Iravani H, Rostami F, Sadati A 2008. Poverty Alleviation and Sustainable Development: The Role of Social Capital. Journal of Social Sciences, 4(3): 202-215.

Bäckstrand K 2006. Democratising Global Environmental Governance: Stakeholder Democracy after the World Summit on Sustainable Development. European Journal of International Relations, 12(4): 467-498. Retrieved April 24, 2010 from: http://ejt.sagepub.com

Baker S 2006. Sustainable Development. London: Routledge.

Blewitt J 2008. Understanding Sustainable Development. London: Earthscan.

Bloch, G. 2009. The Toxic Mix: What's Wrong with South African Schools and How to Fix it. Cape Town: Tafelberg.

Botha RJ 2002: Outcomes-based Education and Educational Reform In South Africa. International Journal of Leadership in Education, 5(4): 361-371.

Boondee V, Kidrakarn P, Sa-Ngiamvibool W 2011. A Learning and Teaching Model using Project-Based Learning (PBL) on a web to Promote Cooperative Learning. European Journal of Social Sciences, 21(3):498-506.

Brandt R (Ed.) 1991. Cooperative Learning and the Collaborative School. Virginia: Association for Supervision and Curriculum Development.

Calder W, Clugston R 2005. Education for a Sustainable Future. Journal of Geography in Higher Education, 29(1): 8-11.

Colantonio, A. 2007. Social Sustainability: An Exploratory Analysis of its Definition. Assessment, Methods, Metrics and Tools. 2007/01: EIBURS Working Paper Series, European Investment Bank.

Department of Basic Education (DBE). 2011. Curriculum and Assessment Policy Statement, Life Orientation, FET (10-12). Pretoria: Government Printers.

De Tocqueville, A. 1969. Democracy in America. Vol.1. New York: Doubleday.

Deb, D. 2009. Beyond Developmentality: Constructing Inclusive Freedom and Sustainability. London: Earthscan

Dillard, J. Dujon, V. and King, M.C. 2009. Understanding the Social Dimension of Sustainability. New York: Routledge.

Dresner, S. 2008. The Principles of Sustainable Development. 2 ${ }^{\text {nd }}$ Edition. London: Earthscan Publications Ltd.

Elliott, J.A. 1994. An Introduction to Sustainable Development: The Developing World. London: Routledge.

Chan Lean Heng. 2006. Re-orientating Teacher Education for Socially Sustainable Development. Paper presented at UNESCO Expert Meeting on Education for Sustainable Development. Bangkok 1-3 May. 
Colantonio A 2007. Social Sustainability: An Exploratory Analysis of its Definition. Assessment, Methods, Metrics and Tools. 2007/01: EIBURS Working Paper Series, European Investment Bank.

Deb D 2009. Beyond Developmentality: Constructing Inclusive Freedom and Sustainability. London: Earthscan.

Department of Basic Education (DBE) 2011. Curriculum and Assessment Policy Statement, Life Orientation, FET(10-12). Pretoria: Government Printers.

Department of Education (DoE) 1995. White Paper on Education and Training (WPET). Pretoria: Government Printers.

Department of Education (DoE) 2001. Manifesto on Values, Education and Democracy. Pretoria: Government Printers.

Department of Education (DoE) 2003. National Curriculum Statement Grades 10-12 (Overview): Pretoria: Government Printers.

De Tocqueville A 1969. Democracy in America. Vol.1. New York: Doubleday.

Dillard J, Dujon V, King MC 2009. Understanding the Social Dimension of Sustainability. New York: Routledge.

Dresner S 2008. The Principles of Sustainable Development. $2^{\text {nd }}$ Edition. London: Earthscan Publications Ltd.

Elliott JA 1999. An Introduction to Sustainable Development: The Developing World. $2^{\text {nd }}$ Edition. London: Routledge.

Enslin P 2006. Democracy, Social Justice and Education: Feminist strategies in a globalising world. Educational Philosophy and Theory, 38(1), 57-67. Retrieved June 21, 2006. www.blackwell-synergy.com

Feldman TR, Assaf S 1999. Social Capital: Conceptual Framerworks and Empirical Evidence: An Annotated Bibliography. Washington: The World Bank.

Fernández SA 2004. 'Sustainability is cool': rhetorical participatory discourse in the Spanish Strategy for Sustainable Development. In: Lafferty, W.M. (Ed.): Governance for Sustainable Development: The Challenge of Adapting Form to Function. Northampton: Edgar Elgar.

Fernando JL 2003. The Power of Unsustainable Development: What is to be done? http://www.ann.sagepub.com: Retrieved September 12, 2008.

Foley J (Ed) 2004. Sustainability and Social Justice. Institute for Public Policy Research. London.

Fukuyama F 1999. Social Capital and Civil Society. Paper prepared for delivery at the IMF Conference on Second Generation Reforms. http://www.imf.org/external/pubs/ft/seminar/1999/reforms/fukuyama.htm. Retrieved April 01, 2011.

Gadotti M 2008. What We Need to Learn to Save the Earth. Journal of Education for Sustainable Development, 2(21): 21-30. 
Georgiadis F, Koutsouri A, Zisimos A 2011. Educational Interventions on 'other-ness': Cooperaitive Learning within Intercultural Children's Literature Teaching in the Muslim Minority Schools in 'Western Thrace'. Journal of Muslim Minority Affairs (31(1): 31-48.

Giroux JJ 1995. Developing Democratic Education. Ticknall: Education Now Books.

Govaris C, Kaldi S. 2008. Promoting Recognition and Acceptance of Cultural Diversity through Cooperative Learning in the Primary School. Proceedings of the IAIE-IASCE International Conference 'Cooperative Learning in Multicultural Societies: Critical Reflections. Retrieved: http://www.iaie.org/1_turinpapers.html, pp.1-11.

Harber C and Mncube V 2011. Is Schooling for the Development of Society? The Case of South Africa. South African journal of Education, Vol. 31:233-245.

Harkness S 2007. Social and Political Indicators of Human Well-Being. In: McGillivray, M (Ed): Human Well-Being: Concept and Measurement. New York: Palgrave Macmillan.

Harley K and Wedekind V 2004. Political change, Curriculum Change and Social Formation. In: Chisholm L. (Ed). Changing Class: Education and Social Change in Post-Apartheid South Africa. London: Zed Books.

Haughton G 1999. Environmental Justice and the Sustainable City. Journal of Planning Education and Research, 18: 233-243.

Heyneman SP 2004. On the International Dimension of Education and Social Justice. Journal of Education: 83-102.

Huh T 2011. Exploring the Principles and Criteria for Governance for Sustainable Development. International Review of Public Administration, 15(3): 67-78.

Jackson MG 2011. The Real Challenge of ESD. Journal of Education for Sustainable Development, 5: 27-37. http://jsd.sagepub.com.

Johnson DW, Johnson RT 2010. Restorative Conflict in School: Necessary Roles of Cooperative Learning and Constructive Conflict. Minnesota: University of Minnesota.

Johnson DW, Johnson RT 1991. Learning Together and Alone: Cooperative, Competitive and Individualistic Learning. $3^{\text {rd }}$ Edition. Boston: Allyn and Bacon.

Johnson DW, Johnson RT, Holubec EJ 1994. Cooperative Learning in the Classroom. Virginia: Association for Supervision and Curriculum Development.

Johnson DW, Johnson RT, Smith K 2007. The State of Cooperative Learning in Postsecondary and Professional Settings. Education Psychology Review, 19:15-29.

Johnson DW, Johnson RT n.d. An Overview of Cooperative Learning. In Johnson, DW; Johnson, RT. Introduction to Cooperative Learning. Cooperative Learning Institute and Interaction Book Company.

Johnson DW, Johnson RT 2010. Peace Education in the Classroom: Creating Effective Peace Education Programs. In: Salomon, G and Edwards, C. (Eds.): Handbook on Peace Education. New York, Psychology Press.

Killen R 2010. Teaching strategies for Quality Teaching and Learning. Claremont: Juta. 
Kilpatrick S, Field J, Falk I 2001. Social Capital: An Analytical Tool for Exploring Life Long Learning and Community Development. University of Tasmania: Discussion Paper D13.

Koning J 2001. Social Sustainability in a Globalised World: Context, Theory and Methodology Explored. Paper Prepared for the UNESCO/MOST Meeting, 22-23 November 2001, The Haque: The Netherlands. www.tilburguniversity.n1/globus/seminarssem02.pdf.

Landorf H, Doscher S, Rocco T 2008. Education for Sustainable Human Development: Towards a definition. Theory and Research in Education, 6: 221 - 236.

Langhelle O 1999. Sustainable Development: Exploring the Ethics of our Common Future. International Political Science Review, 20(2):129-149.

Maceiras R, Cancela A, Urréjola S, Sanchez A 2011. Experience of Cooperative Learning in Engineering. European Journal of Engineering Education, Vol. 36(1):13-19.

Magis K, Shinn C 2009. Emergent Principles of Social Sustainability. In: Dillard, J., Dujon, V. and King, M.C. (Eds): Understanding the Social Dimension of Sustainability. New York: Routledge.

Martin S, Dawe G, Jucker R 2006. Embedding Education for Sustainable Development in Higher Education in the UK. In: Holmberg, J. and Samuelson, B.E. (Eds): Drivers and Barriers for Implementing Sustainable Development in Higher Education. Paris: UNESCO.

McCarthy T 2009. Race, Empire, and the Idea of Human Development. Cambridge: University Press.

McKenzie S 2004. Social Sustainability: Towards Some Definitions. South Australia. Hawke Research Institute, University of South Australia. www.hawkecentre.unisa.edu.au/institute

McLaren D 2003. Environmental Space, Equity and the Ecological Debt. In: Agyeman, J.; Bullard, R.D. and Evans, B. (Eds): Just Sustainabilities: Development in an Unequal World. London: Earthscan Publications Ltd.

Messer WB, Kecskes K 2009. Social Capital and Community: University Partnerships. In: Dillard, J., Dujon, V. and King, M.C. (Eds): Understanding the Social Dimension of Sustainability. New York: Routledge.

Munasinghe M 2009. Sustainable Development in Practice: Sustainanomics, Methodology and Application. Cambridge: University Press.

Murdoch K and Wilson J 2008. Helping your Pupils to Work Cooperatively. London: Routledge.

Muthivhi E, Broom Y 2008. Continuities Across Schooling Transition: A Case of Classroom Practices Among Teachers in Venda, South Africa. Journal of Education Studies, 7(1): 98-121.

Onwuegbuzile AJ, Collins KM, Jiao QG 2009. Performance of Cooperative Learning Groups in a Postgraduate Education Research Methodology Course: The Role of Social Interdependence. Active Learning in Higher Education, 10: 265-277. 
Parveen Q, Mahmood ST, Mahmood A, Arif M 2011. Effect of cooperative learning on academic achievement of $8^{\text {th }}$ Grade Students in the subject of Social Studies. International Journal of Academic Research, 3(1):950-954.

Pendlebury S, Enslin P 2004. Social Justice and Inclusion in Education and Politics: the South African case. Journal of Education, 34: 31-49.

Pronk J 1981. Development and Human Rights. In: Fortman, Bas de Gaay (Ed.): Different Dimensions in Development in the 1980's: A Series of Public Lectures. The Hague: Institute of Social Studies.

Rao PK 2000. Sustainable Development: Economics and Policy. Oxford: Blackwell Publishers.

Rist G 2008. The History of Development: From Western Origins to Global Faith. $3^{\text {rd }}$ Edition. London: Zed Books.

Republic of South Africa (RSA) 1996. The Constitution of the Republic of South Africa, Act 108 of 1996. Pretoria: Government Printers.

Roger T, Johnson DW 1994. An Overview of Cooperative. In: Thousand, J; Villa, A and Nevin, A (Ed.): Creativity and Collaborative Learning. Baltimore: Brookes Press.

Schrueder R 1998. Cooperative Learning as an Approach to Learning Science. European Journal of Intercultural Studies, 9(2): 195-209.

Schul JE 2011. Revisiting an old friend: The Practice and Promise of Cooperative Learning for the Twenty-first Century. The Social Studies, 102: 88-93.

Sekao RD 2004. The Inluence of an Hour-Glass Model of Cooperative Learning on the Learning and Achievement of Grade 8 Mathematics Learners in Crowded Classrooms. Unpublished M.Ed-dissertation: Potchefstroomse Universiteit vir Christelike Hoër Onderwys.

Sen A 1999. Development as Freedom. Oxford: University Press.

Sharan S (Ed.) 1990. Cooperative Learning: Theory and Research. New York: Praeger.

Sharan Y 2010. Cooperative Learning: A Diversified Pedagogy for Diverse Classrooms. Intercultural education, 21(3): 195-203.

Schultz D 2007. Stimulating Social Justice Theory for Service-Learning Practice. In: Calderón, J.Z. (Ed.): Race, Poverty, and Social Justice: Multidisciplinary Perspectives Through Service Learning. Virginia: Stylus Publishing, LLC.

Slavin R 1996. Research on Cooperative Learning and Achievement: What we know, what we need to know. Contemporary Educational Psychology, 21: 43-69.

Slavin R, Chamberlain A, Hurley EA. 2001. Cooperative Learning in the Social Studies: Balancing the Social and Studies. In: Stahl,RJ and Van Sickle, RL. (Eds.): Cooperative Learning in the Social Studies Classroom: An Introduction: $2^{\text {nd }}$ Edition. Tempe Arizona: National Council for the Social Studies Bulletin.

Slavin RE, Cooper R 1999. Improving Intergroup Relations: Lessons Learned from Cooperative Learning Programs. Journal of Social Issues, 55(4):647-663.

Slavin RE 1990. Cooperative Learning: Theory, Research, and Practice. Boston: Allyn and Bacon.

Smith KA 2000. Inquiry-based Cooperative Learning. Minnesota: University of Minnesota.

TD, 9(3), Spec. ed., December 2013, pp. 519-536. 
Sterling S (Ed) 1996. Education for Sustainability. London: Earthscan Publications.

Steyn P, Wilkinson A 1998. Understanding the Theoretical Assumptions of OutcomesBased Education as a Condition for Meaningful Implementation. South African Journal of Education, 18(4): 203-208.

Tsay M, Brady M 2010. A Case Study of Cooperative Learning and Communication Pedagogy: Does working in teams make a difference? Journal of the Scholarship of Teaching and Learning, 10(2): 78-89.

Van Deventer K 2009. Perspectives of Teachers on the Implementation of Life Orientation in Grades R-11 from Selected Western Cape Schools. South African Journal of Education, Vol. 29:127-145.

Wade R, Parker J 2008. EFS-ESD Dialogue: Educating for a Sustainable World. UNESCO: Education for Sustainable Development Policy Dialogue No. 1.

Waghid Y 2003. Education as Virtue: Cultivating Practical Reasoning and Compassion. Stellenbosch: Stellenbosch University Printers.

Wals AEJ 2011. Learning Our Way to Sustainability. Journal of Education for Sustainable Development, 5: 177-186. http://jsd.sagepub.com

Weldon G n.d. 'Thinking Each Other's History' Can Facing the Past Contribute to Education for Human Rights and Democracy?.. http://centres.exeter.ac.uk/historyresource/journa19/papers/weldon.pdf

Wohl A, Klein-Wohl E 1994. Teaching and Learning the Language Arts with Cooperative Learning Methods. In: Sharan Y (Ed.). Handbook of Cooperative Learning Methods. London: Greenwood Press.

World Commission on Environment and Development (WCED)1987. Our Common Future. Oxford: Oxford University Press. 